\title{
NAUKA O WCIELENIU SŁOWA U ŚW. HILAREGO Z POITIERS
}

Przyjęcie natury ludzkiej przez Boga Słowo zajmuje w myśli teologicznej Hilarego z Poitiers miejsce szczególne: „Verbum Deus caro factum est, ut per Deum verbum carnem factum caro proficeret in Deum verbum"1 - pisał Hilary w jednym z pierwszych rozdziałów podstawowego swojego dzieła De Trinitate. Od owego wielkiego misterium zbawienia „sacramentum nostrae salutis” - jak określa to często Hilary ${ }^{2}$ - rozpoczyna się nowa epoka w historii objawienia. Dla Biskupa Poitiers wcielenie Słowa Bożego stanowi decydujący etap objawienia Bożego planu zbawienia. Taka myśl zdaje się wynikać choćby z hilariańskiej egzegezy ewangelicznej przypowieści o gospodarzu najmującym robotników do pracy w swojej winnicy (Mt 20,1-16). Jedenasta godzina dnia z tej przypowieści symbolizuje $w$ interpretacji Hilarego przyjście Pana w ciele ${ }^{3}$. W innym miejscu idąc za myślą z pierwszego listu do Tymoteusza ${ }^{4}$ Hilary podkreśla $\mathrm{z}$ naciskiem, że tajemnica wcielenia stanowi o objawieniu $\mathrm{w}$ ciele „mysterium pietatis"5.

Nauczanie Hilarego na temat wcielenia Słowa jest obecne we wszystkich jego dziełach, a w sposób szczególny w dwu pismach: Tractatus super Psalmos i De Trinitate. Pod adresem tych pism postawmy pytania o naturę tajemnicy wcielenia, jej godność i sens, a także o terminologię przy pomocy której Biskup Poitiers wypowiada swoją naukę na ten temat.

${ }^{1}$ De Trinitate I, 11, CCL 62, 11.

2 Por. np. De Trinitate IX 56 i XI 9, CCL 62A, 435 i 537; Tractatus super Psalmos 138,2, CSEL 22,745 .

${ }^{3}$ Por. In Matthaeum 20,6, SCh 258, 108.

${ }^{4}$ Por. $1 \mathrm{Tm}$ 3,16: „A bez wątpienia wielka to jest tajemnica pobożności. Ten, który objawił się w ciele, usprawiedliwiony został w Duchu, ukazał się aniołom, ogłoszony został poganom, znalazł wiarę w świecie, wzięty został w chwale".

${ }_{5}$ Por. De Trinitate XI 9, CCL 62A, 537-539. 


\section{HILARIAŃSKA INTERPRETACJA FLP 2,6-8}

Kluczowym tekstem biblijnym, który stanowi podstawę nauczania Biskupa Poitiers na temat wcielenia, jest fragment listu św. Pawła Apostoła do Filipian:

„On, istniejąc w postaci Bożej, nie skorzystał ze sposobności, aby na równi być z Bogiem, lecz ogołocił samego siebie, przyjąwszy postać sługi, stawszy się podobnym do ludzi. A w zewnętrznym przejawie, uznany za człowieka, uniży samego siebie, stawszy się posłusznym aż do śmierci - i to śmierci krzyżowej” (Flp 2,6-8).

Interpretacja tego tekstu stanowi o wielu wypowiedziach Biskupa Poitiers na temat wcielenia. Koncentruje się ona na dwu kluczowych tutaj słowach: „forma Dei” (postać Boga) i „forma servi” (postać sługi). W interpretacji Biskupa Poitiers, Chrystus w fakcie wcielenia opuścił postać Boga i przywdział postać sługi.

W jednej z wypowiedzi Hilary wyraża się w sposób następujący:

„Lecz w rozporządzeniu przyjęcia ciała i poprzez posłuszeństwo ogołociwszy się z postaci boskiej, Chrystus jako zrodzony człowiek dodał sobie nową naturę, nie przez utratę naturalnej mocy, lecz poprzez zmianę postaci. Ogołociwszy się przeto z postaci Bożej, jako zrodzony przyjął postać sługi, ale natura Ojca, z którą on był w naturalnej jedności nie odczuła tego przyjęcia ciała, podczas gdy Chrystus, chociaż zachował moc natury, utracil jednak na pewien czas ze względu na przyjęte człowieczeństwo jedność z postacią Boga, a także z Bożą naturą"6.

W powyższym tekście, w którym tajemnica wcielenia określona jest słowami „dispensatio adsumptae carnis", Biskup Poitiers wskazuje na fakt ogołocenia się Chrystusa z postaci boskiej na skutek zmiany postaci, z boskiej - na postać sługi. Poprzez fakt wcielenia nastąpiło „demutatio habitus” (zmiana postaci). Badacze myśli teologicznej św. Hilarego thumaczą, że Hilary rozumie „forma Dei” czy też analogicznie „forma servi” jako „habitus”, mając na myśli zewnętrzny aspekt, w którym objawia się natura ${ }^{7}$. „Demutatio habitus” oznaczałoby więc zmianę zewnętrznego aspektu, w którym objawia się natura. Zmiana ta, stanowiąca o fakcie wcielenia, miała, jak wskazuje w analizowanym tekście Biskup Poitiers, charakter czasowy. Przyjęcie „forma servi” jest tutaj dla Hila-

${ }^{6}$ De Trinitate IX 38, CCL 62A, 411-412: „Sed dispensatione adsumptae carnis et per exinanientis se ex Dei forma oboedientiam, naturae sibi novitatem Christus homo natus intulerat, non virtutis naturaeque damno sed habitus demutatione. Exinaniens se igitur ex Dei forma, servi formam natus acceperat; sed hanc carnis adsumptionem ea cum qua sibi naturalis unitas erat Patris natura non senserat; et novitas temporalis, licet maneret in virtute naturae, amiserat tamen cum forma Dei, naturae Dei secundum adsumptum hominem unitatem".

7 Por. P. Coustant, Praefatio generalis (do wydania dziel św. Hilarego) PL 9, 11-126; A. Orazzo, La salvezza in Ilario di Poitiers. Cristo Salvatore dell'uomo nei „Tractatus super Psalmos", Napoli 1986, 40-41. 
rego równoznaczne z przyjęciem ludzkiej natury. To świadczy wyraźnie, że Chrystus po wcieleniu stał się człowiekiem. Jak jednak przedstawia się w tym przypadku sprawa z bóstwem Chrystusa? W analizowanym przez nas tekście Biskup Poitiers podkreśla utrzymanie naturalnej mocy (natura virtutis) po akcie przybrania postaci sługi. Stwierdza jednak, że Chrystus na pewien czas, ze względu na przyjęte człowieczeństwo, utracił jedność z postacią Boga, a także z jego naturą. Czy to oznacza, że Chrystus utracił, chociaż tylko na pewien czas, naturę boską?

Wiele innych wypowiedzi Hilarego, gdzie rozważa on kwestię ogołocenia się Chrystusa z postaci boskiej, zdecydowanie przeczy takiemu przypuszczeniu. W analizowanym powyżej tekście Hilary wyraźnie utożsamia „natura Dei” z „virtus Dei”, a Chrystus po wcieleniu zachował moc natury, jaką przed wcieleniem miał z Ojcem. Przytoczmy jeszcze jeden tekst z traktatu De Trinitate, w świetle którego „natura Dei” wyraża się w „virtus Dei”, a co odnosi Hilary bardzo wyraźnie do Chrystusa po wcieleniu:

\begin{abstract}
„[Chrystus] posiadał właściwą sobie naturę, lecz postaci Boga już nie posiadał, ponieważ na skutek wyzbycia się jej przyjął postać sługi. Nie stracił bowiem natury, lecz zachowując w sobie naturę Boga przyjął na siebie upokorzenie, wynikające $\mathrm{z}$ ziemskiego narodzenia. $\mathrm{W}$ tej pokornej postawie, jaką przyjąl, objawił moc, która była wynikiem jego pochodzenia. Tak Bóg z Boga narodzony, osiągnąwszy w postaci sługi człowieczeństwo, działa jako Bóg w swojej mocy. Jednocześnie był człowiekiem, w którego postaci się znalazł i Bogiem, co wykazał swoimi czynami" ${ }^{\circ}$.
\end{abstract}

W świetle tego tekstu, gdzie Hilary po raz kolejny nawiązuje do tekstu św. Pawła z Listu do Filipian, deklaruje się w stanowczy sposób, że Chrystus pozostając w naturze Bożej, przez co rozumie przede wszystkim zachowanie w Chrystusie „virtus Dei”, przyjął na siebie wszelkie upokorzenia, jakie wiążą się z jego ziemskim narodzeniem i staniem się człowiekiem w postaci sługi. Tę boską naturę, przejawiającą się w boskiej mocy, okazał światu przebywając w ludzkiej postaci poprzez czyny świadczące o mocy boskiej potęgi. Po raz kolejny jednak w tym tekście Hilary deklaruje, że po wcieleniu Chrystus nie posiadał już „forma Dei”. W jakiej przeto relacji w teologicznej myśli Biskupa Poitiers pozostaje „forma Dei” do „natura Dei”?

W twierdzeniu, że Chrystus był w postaci Boga (in forma Dei) teologia IV wieku znajdowała ważne świadectwo na rzecz bóstwa Syna. W ten sposób choćby Ambroży rozważa równoważność formuł „in forma Dei” i „in

${ }^{8}$ De Trinitate IX 51, CCL 62A, 429-430: „Erat enim naturae proprietas, sed Dei forma iam non erat, quia per eius exinanitionem servi erat forma suscepta. Neque enim defecerat natura, ne esset, sed in se humilitatem terrenae nativitatis manens sibi Dei natura susceperat, generis sui potestatem in habitu adsumptae humilitatis exercens. Et ex Deo Deus natus, in forma servi homo repertus, Deum se virtutibus agens, neque Deus non erat, quem gestis suis docebat; neque homo, in cuius habitu repertus est, non manebat". 
divinitatis plenitudine" ". Także i dla Hilarego istnienie w „forma Dei” nie jest czymś innym, niż istnienie na sposób Boga: „Esse autem in forma Dei non alia intellegentia est, quam in Dei manere natura"10. To wskazywałoby, że Hilary stawia znak równości pomiędzy „forma Dei” a „natura Dei”. Jak wówczas rozumieć jego stwierdzenia, że Chrystus pozostając w naturze boskiej w momencie wcielenia ogołocił się z postaci Boga? Czy nie znaleźlibyśmy się wówczas w kręgu sprzeczności? Przytoczmy na ten temat jeszcze jeden tekst Biskupa Poitiers z Tractatus super Psalmos, z komentarza do Psalmu 68:

\begin{abstract}
„Przybywając bowiem w postaci sługi ogołocił się z postaci Boga. Albowiem któż mógłby istnieć w postaci ludzkiej pozostając jednocześnie w postaci Boga? Postać Boga zaś nie mogła ulec zniszczeniu, by pozostała tylko postać sługi. Ten sam bowiem ogołociwszy się z postaci Boga, przyjmuje postać człowieka, gdyż ani to ogołocenie z postaci Boga nie jest zniszczeniem niebieskiej natury, ani przyjęcie postaci sługi nie dokonuje się jakby w naturze i warunkach naturalnego stanu, ponieważ to, co przyjęto nie jest wewnętrzną właściwością lecz zewnętrznym przystąpieniem" $"$.
\end{abstract}

Spróbujmy dokonać gruntownej analizy tej bardzo ważnej wypowiedzi. Tekst wydaje się stwierdzać po pierwsze niezgodność pomiędzy „forma Dei” a „forma servi”: „In forma enim servi veniens evacuavit se ex Dei forma. Nam in forma hominis existere manens in Dei forma qui potuit"? Taki kontekst wskazuje tutaj na specyficzne rozumienie przez Hilarego sensu pojęcia „postać Boga”. Odwołajmy się w tym momencie raz jeszcze do tekstu o wcieleniu jako o „demutatio habitus” i znaczenia, jakie posiada "habitus” w myśli teologicznej Biskupa Poitiers. Sens „,forma Dei” zdaje się tutaj ograniczać do stanu boskiej chwały i majestatu. „Forma Dei” w takim znaczeniu, jako istotny aspekt „natura Dei”, może być porównana do „splendor” czy "maiestas Dei”, co stanowi o zewnętrznym aspekcie boskiej natury, nie daje się w żadnym razie pogodzić z „forma servi” albo „forma hominis”. Przez te dwa ostatnie pojęcia Hilary w analizowanym tekście zdaje się wyraźnie wskazywać na treści związane z ludzką stroną tajemnicy wcielenia. W takim znaczeniu „forma Dei” jest czymś zewnętrznym wobec „forma servi”, przez którą Hilary z jednej strony rozumie naturę ludzką, a z drugiej wszelkie warunki,

${ }^{9}$ Por. A. Orazzo, La salvezza, dz. cyt., s. 37.

${ }^{10}$ De Trinitate XII 6, CCL 62A, 583: „Istnienia zaś w postaci Bożej nie należy rozumieć inaczej niż jako trwanie w naturze Boga".

11 Tractatus super Psalmos 68, 25, CSEL 22, 334: „In forma enim servi veniens evacuavit se ex Dei forma. Nam in forma hominis existere manens in Dei forma qui potuit? Aboleri autem Dei forma, ut tantum servi esset forma, non potuit. Ipse enim est et se ex forma Dei inaniens et formam hominis adsumens, quia neque evacuatio illa ex Dei forma naturae caelestis interitus est, neque formae servilis adsumptio tamquam genuinae originis condicionisque natura est, cum id, quod adsumptum est, non proprietas interior sit sed exterior accessio". 
w jakich odbywa się służba człowieka. Po drugie jednak kolejne stwierdzenie w tym samym tekście wskazuje na coś jakby przeciwnego, to znaczy na fakt współistnienia „forma Dei” i „forma servi”: „Aboleri autem Dei forma, ut tantum servi esset forma, non potuit”. W tym kontekście „forma Dei” zdaje się przybierać bardziej szeroki i głęboki sens natury boskiej. Przy takim rozumieniu ,forma Dei” Biskup Poitiers mówi o wspólistnieniu po wcieleniu „forma Dei” i „forma servi”, a „forma Dei” jest równoznaczna z naturą boską w jej najgłębszym wewnętrznym sensie. To wspólistnienie z ,forma Dei” w tak rozumianym znaczeniu mogło zaistnieć z "forma servi” nie poprzez zmieszanie $\mathrm{z}$ wewnętrzną właściwością natury ludzkiej (non proprietas interior), lecz poprzez zewnętrzne przystąpienie (exterior accessio). Czy w tym ostatnim sformułowaniu można się domyślać w myśli hilariańskiej zwiastuna nestorianizmu? Istnienia dwu Chrystusów? Hilary wyraźnie mówi o jedności Słowa wcielonego.

Tytułem podsumowania analizy powyższego tekstu możemy stwierdzić, że w myśli teologicznej Biskupa Poitiers pojęcie „forma Dei” występuje w dwojakiego rodzaju znaczeniu. Po pierwsze, w szerszym znaczeniu wskazuje na naturę samego Boga, w znaczeniu zaś węższym na stan boskiej chwały i majestatu. W tym pierwszym znaczeniu można powiedzieć, że Chrystus Wcielone Słowo jest we wszystkim równy Bogu. To drugie natomiast znaczenie nie pozwala dopuszczać współistnienia „forma Dei” ze stanem pokory i poddania, jakie Hilary podkreśla w fakcie wcielenia w wielu różnych miejscach swoich pism. Korelatywnie, jak podkreślono, Hilary mówi o „forma hominis” czy też „forma servi” bądź „forma servilis”. „Forma hominis” wskazuje na naturę ludzką Chrystusa, „forma servi” na warunki służby i pokory, jakie Chrystus przyją ${ }^{12}$.

Dokonana analiza kilku wybranych tekstów, w których Hilary dokonuje interpretacji słów Pawła Apostoła z Listu do Filipian pozwala na wydobycie kilku tez, jakie $\mathrm{z}$ tej interpretacji uzyskuje Biskup Poitiers na rzecz nauki o wcieleniu Słowa. Po pierwsze, nie jest możliwe, aby Słowo Boże przyjeło postać sługi pozostając w postaci Bożej, która wyraża Boży majestat i chwałę. Po drugie, to samo Słowo ogołociło się z ,forma Dei” i przyjęło „forma servi”. Po trzecie wreszcie „exinanitio se ex forma Dei” nie oznacza, że Słowo wcielone utraciło naturę Boga, albowiem przyjęcie „forma servi” dokonało się poprzez zewnętrzne przyjęcie, które w niczym nie zaszkodziło pełni bóstwa Słowa, jakie jako Jednorodzony Bóg posiadał na podstawie doskonałego i niewypowiedzianego zrodzenia, jakie dokonało się w naturze boskiej ${ }^{13}$.

${ }^{12}$ Por. P. Galtier, La „forma Dei” et la ,forma servi” selon Saint Hilaire de Poitiers, RSR 48(1960) 101-110; P. Orazzo, La salvezza, dz. cyt., s. 40-41.

13 Por. De Trinitate IX 37, CCL 62A, 411. 


\section{TOŻSAMOŚĆ SŁOWA WCIELONEGO}

„Deus Verbum caro factum est”. W tajemnicy wcielenia Bóg Słowo stał się ciałem. Kolejne pytanie, jakie należy postawić dotyczy tożsamości Słowa Wcielonego, kim w istocie swojej było wcielone Słowo Boga?

1. Odwieczne zrodzenie Słowa przez Ojca. "Deus Verbum" w myśli Hilarego - to jednorodzony Syn Boga. W duchu polemiki z doktryną ariańską Biskup Poitiers podkreśla prawdziwe bóstwo Słowa na równi z Ojcem. „Ponieważ prawdziwy i jeden jest Syn, nie mógł stać się synem wyrodnym i narodzić się z niczego" 14 . W De Trinitate Hilary mówi o boskim zrodzeniu Słowa przez Ojca. „Filius Dei” jako prawdziwy Bóg nie został stworzony z niczego, ale jest Bogiem na podstawie doskonałego i niewypowiedzianego zrodzenia przez Ojca. Jest to niecielesne zrodzenie niecielesnej natury, poprzez które żywy i prawdziwy Bóg pochodzi od żywego i prawdziwego Boga, jest Bogiem $\mathrm{z}$ natury, ponieważ narodzenie, jakie zaistniało nie dokonało się $\mathrm{w}$ innej naturze niż boska ${ }^{15}$. W Tractatus super Psalmos w komentarzu do Psalmu 122 Biskup Poitiers dodaje:

„Należy wierzyć, że Bóg z Boga zrodzony, uczestniczy w naturze tego, który go zrodzil i niezrodzony Bóg rodząc Boga jednorodzònego pozostaje w tym, którego zrodził w właściwym sobie zrodzeniu" ${ }^{16}$.

Tę wypowiedź na temat pełnej natury boskiej Słowa uzupełniają inne słowa Biskupa Poitiers z komentarza do Psalmu 138:

„Jest bowiem z niego zrodzony, ale nie ma w nim obcej natury nowego stworzenia.

Syn jest w mocy, syn jest w bóstwie, Syn jest w naturze, Syn jest w zrodzeniu"17.

„Deus Verbum” jako jednorodzony Syn Boga posiada więc „plenitudo divinitatis" (pełnię bóstwa), która zasadza się na tej samej boskiej naturze i mocy.

2. Prawdziwe bóstwo Chrystusa. Ta pełnia bóstwa Słowa ma swój pełny i rzeczywisty udział w tajemnicy wcielenia. Hilary ujmuje tę prawdę bardzo

14 Tamże III 22, CCL 62, 94: „Sed quia uerus unus est Filius, non fiat degener, ut natus ex nihilo sit".

${ }^{15}$ Por. tamże IX 37, CCL 62A, 411.

16 Tractatus super Psalmos 122,2, CSEL 22, 581: „Deus enim ex Deo genitus non abest per naturam ab eo, ex quo genitus confitendus est: et Deus innascibilis unigenitum Deum gignens manet in illo, quem genuit proprietate generandi".

17 Tractatus super Psalmos 138,35, CSEL 22, 769: „Est namque genitus ex eo, non est in eo novae creationis aliena natura. Virtute filius est, divinitate filius est, substantia filius est, generatione filius est". 
krótko, że w Chrystusie cieleśnie zamieszkuje pełnia bóstwa ${ }^{18}$. Chrystus jest prawdziwym Bogiem. Tę prawdę Hilary wydobywa choćby dokonując interpretacji słów Chrystusa: „Ja i Ojciec jedno jesteśmy” (J 10,30). Chociaż różni ich właściwość, jaka zawiera się w imionach, „Ojciec” i „Syn”, to o trwaniu Syna w tej samej boskiej naturze świadczy jedność woli, ta sama boska moc i odbieranie tej samej chwały, jaką odbiera Ojciec ${ }^{19}$. Chrystus jest ,inseparabilis” i ,indifferens” od jedynego i prawdziwego Boga ${ }^{20}$. Po wcieleniu Słowo utrzymało jedność z naturą boską ${ }^{21}$.

3. Prawdziwe człowieczeństwo Chrystusa. Jezus Chrystus, wcielone Słowo Boga jest $\mathrm{z}$ jednej strony prawdziwym Bogiem a z drugiej prawdziwym człowiekiem. Bóg Słowo nie stał się ciałem innym niż jest nasze ciało. On zamieszkał wśród nas jako doskonały i prawdziwy pośród swoich ${ }^{22}$. „On jest prawdziwym Synem człowieczym, to, że urodził się z Boga w żaden sposób nie umniejsza jego człowieczeństwa, ani nie umniejsza jego bóstwa, ponieważ urodził się jako człowiek" ${ }^{23}$ stwierdzał w De Trinitate Biskup Poitiers. Prawdziwość i pełnia człowieczeństwa w Chrystusie zasadza się na realizmie jego ziemskiego poczęcia i narodzenia. Biskup Poitiers wyraża ten realizm w następujących słowach:
„Na skutek nie dającego się opisać słowami boskiego pochodzenia, jeden, jedno- rodzony Bóg, wprowadzony w łono świętej dziewicy, nabierał kształtu ludzkiego ciałka. Ten, który zawiera wszystko i wewnątrz którego i przez którego jest wszystko, narodził się zgodnie z prawem ludzkich narodzin. Na głos, którego truchleją archaniołowie i aniołowie, otwierają się niebo i ziemia i wszystkie ele- menty tego świata, jest słyszany w kwileniu niemowlęcia. Ten, który jest niewi- dzialny i niepojęty może być pojęty przy pomocy zmysłów wzroku i dotyku i zamkną się w kobiecym łonie" ${ }^{24}$.

a. Dusza ludzka w Chrystusie. Przez ową doskonałość i prawdziwość człowieczeństwa w Chrystusie Hilary rozumie, że było ono wyposażone w duszę i ciało. Ujmuje to następującym porównaniem:

${ }^{18}$ Por. De Trinitate I,13, CCL 62, 14.

19 Por. Tractatus super Psalmos 138,17, CSEL 22, 756-757.

${ }^{20}$ Por. De Trinitate IX 39, CCL 62A, 413.

${ }^{21}$ Por. tamzie IX 38, CCL 62A, 411- 412.

22 Por. tamze I 11, CCL 62, 11-12.

23 Tamże X 21, CCL 62A, 475: ,[...] ut vere Dei Filius verus hominis filius natus sit, neque non natus ex Deo homo, neque quia natus ex Deo homo ideo Deus esse deficiens".

${ }^{24}$ Tamże II 25, CCL 62, 61: „Inenarrabilis a Deo originis unus unigenitus Deus in corpusculi humani formam sanctae virginis utero insertus adcrescit. Qui omnia continet, et intra quem et per quem cuncta sunt, humani partus lege profertur. Et ad cuius vocem archangeli adque angeli tremunt, caelum et terra et omnia mundi huius resolventur elementa, vagitu infantiae auditur. Qui invisibilis et inconpraehensibilis est, non visu sensu tactuque moderandus, cunis est obuolutus". 
„,[jak] człowiek narodził się z ciała i duszy, tak Jezus Chrystus przez moc swoją był z ciała i duszy człowiekiem" 25 .

Jak w każdym człowieku znajdują się elementy rozrodcze, podczas gdy dusza została stworzona wprost przez Boga, tak w Chrystusie, który był zrodzony jedynie z Dziewicy bez współudziału mężczyzny, należy uznać, że dusza nie została przekazana podczas zrodzenia cielesnego, ale pochodzi bezpośrednio od Boga ${ }^{26}$. Podobne poglądy w duchu antyheretyckiej polemiki wyraża Biskup Poitiers w innym miejscu, gdy stwierdza:

„Chociaż liczni przy pomocy sztuki usiłują dowieść swej herezji i w ten sposób mają w zwyczaju oszukiwać uszy ludzi niedoświadczonych, że zarówno ciało jak i dusza Adama były grzeszne, tak, iż Pan powinien przyjąć ciało i duszę z Dziewicy, i że nie był to cały człowiek, jakiego Dziewica poczęła z Ducha Świętego. Gdyby oni rozumieli tajemnicę wcielenia, zrozumieliby tym samym tajemnicę Syna Człowieczego i Syna Bożego. Jak gdyby z Dziewicy przyjął tylko ciało, przyjąłby także $\mathrm{z}$ niej i duszę; chociaż wszelka dusza jest dziełem Boga, ciało zawsze rodzi się $\mathrm{z}$ ciała" 27 .

Hilary mówiąc o człowieczeństwie Chrystusa wypowiada się więc wyraźnie o jego ludzkiej duszy. Są to bardzo ważne stwierdzenia, jak na teologa z połowy IV wieku. Współczesny mu teolog wschodni Atanazy z Aleksandrii, poruszając się w swoim myśleniu teologicznym wokół schematu chrystologicznego

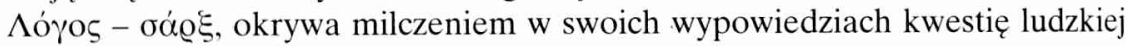
duszy Chrystusa. Przewaga zwanego „Atanazym Zachodu” Hilarego nad teologiem aleksandryjskim jest więc w tym punkcie widoczna. Hilary zdaje się

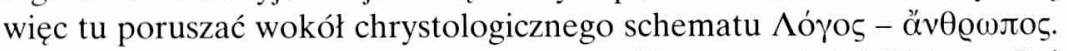

Czy rzeczywiście zważywszy na wszystkie wypowiedzi Biskupa Poitiers, dotyczące tajemnicy Chrystusa, sprawa ta przedstawia się tak prosto i jednoznacznie? Niektóre wypowiedzi Biskupa Poitiers zdają się wskazywać, że jego myśl obraca się także wokół innego schematu chrystologicznego. W jednym miejscu De Trinitate Hilary odnosząc się do tajemnicy wcielenia stwierdza: „Spiritus manifestatur in carne”28. W Tractatus super Psalmos mówi on

25 Tamże X 19, CCL 62A, 473-474: „[sicut] corporis adque animae homo nascitur, ita lesus Christus per virtutem suam carnis adque animae homo ac Deus esset, habens in se et totum verumque quod homo est et totum verumque quod Deus est".

26 Por. tamże X 22, CCL 62A, 475.

27 De Trinitate X 20, CCL 62A, 474: „Quamquam multi confirmandae hereseos suae arte ita aures inperitorum soleant inludere, ut quia et corpus et anima Adae in peccato fuit, carnem quoque Adae adque animam Dominus ex virgine acceperit, neque hominem totum ex Spiritu Sancto virgo conceperit. Qui si intellegerent sacramentum carnis adsumptae, intellegerent et sacramentum eiusdem et hominis fili et Dei Fili. Quasi vero si tantum ex virgine adsumpsisset corpus, adsumpsisset quoque ex eadem et animam: cum anima omnis opus Dei sit, carnis vero generatio semper ex carne sit".

${ }^{28}$ Tamże XI 9, CCL 62A, 538. 
o wewnętrznej jedności w Chrystusie pomiędzy „Spiritus deitatis” a „origo carnis" "29. Mamy więc tutaj do czynienia z innym schematem, mianowicie „Spiritus” - „caro”. Według L. F. Ladaria schemat „Spiritus” - „caro” koresponduje zawsze we wszystkich pismach hilariańskich ze schematem bóstwo człowieczeństwo i generalnie duch nie wskazuje na duszę ludzką lecz na bóstwo $^{30}$. Z drugiej strony, jak wskazaliśmy, Hilary przynajmniej teoretycznie uznaje istnienie duszy ludzkiej w Chrystusie. Według A. Grillmeiera Biskup Poitiers uznając w Chrystusie istnienie ludzkiej duszy, nie czyni jednak z tego pełnowartościowego czynnika teologicznego ${ }^{31}$.

b. Ciało Chrystusa a nasze ciało. Jak z kolei w myśli chrystologicznej Hilarego przedstawia się kwestia kondycji cielesnej w ramach człowieczeństwa Chrystusa? Ta cielesna kondycja sprawia, że na równi ze wszystkimi ludźmi Chrystus łaknął, pragnął, spał, był zmęczony, smucił się, płakał i cierpiał ${ }^{32}$, a także miał ludzkie oczekiwania ${ }^{33}$. Z drugiej jednak strony Biskup Poitiers wskazuje, iż ze względu na fakt, że ciało Chrystusa zostało poczęte w inny sposób niż nasze ciało, Chrystus znosił różne słabości, ale nie były to słabości jego natury. Na szczególną uwagę zasługuje tu następujący tekst:

\begin{abstract}
„Zobaczyliśmy moc, jaka znajduje się w czynach i słowach Jezusa. W sposób bezsporny wykazaliśmy, że w naturze jego ciała nie było słabości natury cielesnej, ponieważ jego moc mogłaby usunąć słabości ciała, tak, iż kiedy on cierpiał, jego ciało znosiło cierpienie, ale nie zadawało to cierpienia jego naturze: działo się tak, ponieważ, chociaż postać naszego cierpienia była w Panu, jednak On na skutek mocy, jaka wynikała z jego pochodzenia, nie był w ciele naszej słabości i niedoskonałości. On począł się z Ducha Świętego i narodził z Dziewicy, co spełniało funkcję płci, ale jego poczęcie nie dokonało się z nasienia człowieka. Ona porodziła ciało, ale poczęcie było dziełem Ducha Świętego; było to ciało, które posiadało wrodzoną rzeczywistość, ale bez słabości wynikających z jego natury. To ciało było prawdziwym i rzeczywistym ciałem, ponieważ porodziła je dziewica: ale przekraczało ono granice słabości naszego ciała, ponieważ jego początek miał miejsce w duchowym poczęciu" ${ }^{\text {"34 }}$.
\end{abstract}

${ }^{29}$ Por. Tractatus super Psalmos 131,16, CSEL 22, 674: „Nunc et deitatis spiritu et origine carnis unitum intus [...]".

${ }^{30}$ Por. L. F. Ladaria, El Espiritu Santo en San Hilario de Poitiers, Madrid 1977, 111.

${ }^{31}$ Por. A. Grillmeier, Jesus der Christus im Glauben der Kirche, Bd.1: Von der Apostolischen Zeit zum Konzil von Chalcedon, Freiburg 1979, 584.

32 Por. Tractatus super Psalmos 53,7, CSEL 22, 140: „Ex communi nostra infirmitate salutem sibi est deprecatus a Patre, ut nativitatem nostram cum ipsis infirmitatis nostrae inisse intellegeretur officiis. Hinc illud est, quod esurivit, sitivit, dormivit, lassatus fuit, impiorum coetus fugit, maestus fuit et flevit et passus et mortuus est".

33 Por. Tractatus super Psalmos 54,2, CSEL 22, 147-148.

${ }^{34}$ De Trinitate X 35, CCL 62A, 488-489: „Conlatis igitur dictorum adque gestorum virtutibus demonstrari non ambiguum est, in natura eius corporis infirmitatem naturae corporeae non fuisse, cui in virtute naturae fuerit omnem corporum depellere infirmitatem; et passionem illam, licet 
W świetle tego tekstu możemy wyraźnie zauważyć, że Hilary uznaje w Chrystusie z jednej strony realność cech właściwych każdemu człowiekowi, z drugiej zaś podkreśla, że człowieczeństwo Chrystusa umocnione było nadzwyczajną mocą, która wynikała z faktu poczęcia go mocą Ducha Świętego. To duchowe poczęcie Słowa wcielonego stanowi o wielkiej godności tajemnicy wcielenia, którą Biskup Poitiers wyraża w następujących słowach:

„Skrupulatne umysły nie powinny w swoich rozważaniach zatrzymywać się tylko nad kwileniami, jakie wydobywają się z kołyski narodzonego, a także nad samym poczęciem. Stąd należy w tym przypadku zwrócić uwagę na godność Boga [...], anioł chwali Maryję, że jako dziewica ofiaruje się zostać Matką Syna Bożego. Ją, która w świadomy sposób wybrała drogę dziewictwa, fakt ten wprawia w zakłopotanie. Stąd anioł wyjaśnia, że rzeczywistość ta dokona się na skutek Bożego działania. Rzecze bowiem: «Duch Święty zstąpi na ciebie i moc Najwyższego osłoni cię» (Łk 1,35). Duch Święty zstępując z wysoka uświęcił wnętrze dziewicy i tchnąc w nie, ponieważ duch tchnie, gdzie chce, dokonal połączenia się z naturą ludzkiego ciała i to co było dla niego obce, przyjął swoją mocą i władzą. Moc Najwyższego osłoniła Dziewicę, aby ze względu na ułomność ludzkiego ciała nie nastąpiło coś niestosownego, słabość jej jakby przez cień rozlany wokół umocnił Duch Święty, osłaniając czynną substancję cielesną, gdy zstąpił celem spowodowania poczęcia. Taka jest godność poczęcia ${ }^{35}$.

Do tej samej godności poczęcia Hilary nawiązywał wcześniej w Commentarius in Mathaei Evangelium, gdy dokonując egzegezy Ewangelii dzieciństwa według św. Mateusza bronił dziewictwa Maryi. Powołując się na dwa wersety z Ewangelii według św. Mateusza: „Wpierw nim zamieszkali razem, znalazła się brzemienną za sprawą Ducha Świętego” (Mt 1,18) i „Józefie, synu Dawida, nie bój się wziąć do siebie Maryi, twej małżonki” (Mt 1,20), podkreślał, że aby nie było żadnej niejasności co do narodzenia Jezusa, Józef sam przyjął świadectwo

inlata corpori sit, non tamen naturam dolendi corpori intulisse. Quia quamuis forma corporis nostri esset in Domino, non tamen in vitiosae infirmitatis nostrae esset corpore, qui non esset in origine, quod ex conceptu Spiritus Sancti virgo progenuit: quod licet sexus sui officio genuerit, tamen non terrenae conceptionis suscepit elementis. Genuit etenim ex se corpus, sed quod conceptum esset ex Spiritu, habens quidem in se sui corporis veritatem, sed non habens naturae infirmitatem: dum et corpus illud corporis veritas est, quod generatur ex virgine, et extra corporis nostri infirmitatem est, quod spiritalis conceptionis sumpsit exordium”.

${ }^{35}$ De Trinitate II 26, CCL 62, 61-62: „Sed ne forte detineant scrupulosas mentium cogitationes cunae vagitus partus adque conceptio, reddenda est singulis Dei dignitas, [...] Mariam angelus benedicit, matrem Fili Dei virginem pollicetur. Illa virginitatis suae conscia difficultate facti commovetur. Angelus efficientiam divinae operationis exponit. Ait enim: «Spiritus Sanctus superveniet in te et virtus Altissimi obumbrabit tibi». Spiritus Sanctus desuper veniens virginis interiora sanctificauit, et in his spirans - quia ubi vult Spiritus spirat - naturae se humanae carnis inmiscuit, et id quod alienum a se erat vi sua ac potestate praesumpsit. Adque ut ne quid per inbecillitatem humani corporis dissideret, virtus Altissimi virginem obumbravit, infirmitatem eius veluti per umbram circumfusa confirmans, ut ad sementivam ineuntis Spiritus efficaciam substantiam corporalem divinae virtutis inumbratio temperaret. Haec conceptionis est dignitas". 
o Jego poczęciu z Ducha Świętego, a następnie, ponieważ Maryja była mu zaślubiona, przyjął ją jako małżonkę, a raczej to Maryja przyjęła imię małżonki Józefa, ponieważ ten poznał ją, ale nie połączył się $\mathrm{z}$ nią̧ ${ }^{36}$.

O wynikającej z godności poczęcia mocy ciała Chrystusa, które stanowiło o przewadze Jego ciała nad naszym ciałem, Biskup Poitiers mówi także wyraźnie, gdy podkreśla cielesną moc Chrystusa wobec czekającej go męki:

„Czy On bał się, kiedy wyszedł naprzeciw uzbrojonym bandom, które przyszły Go pojmać? Słabość w jego ciele, do której zbliżali się prześladowcy, wirowała i łamała ich szeregi tak, że padli na twarz niezdolni do zniesienia Jego majestatu, a On sam zaproponował, aby go skuli? Co za słabość mogła podbić Jego ciało? Czyja natura miała taką potęgę" ${ }^{37}$ ?

W innym jeszcze miejscu Biskup Poitiers następująco wyraża tę szczególną cudowną właściwość ludzkiego ciała Chrystusa:

„Jak możemy ocenić naturę ludzkiego ciała, które poczęło się z Ducha Świętego? To ciało jest chlebem z nieba, $i$ ten człowiek jest od Boga. On ma wprawdzie ciało zdolne do cierpienia, i cierpiał, ale nie miał on żadnej natury, aby cierpieć. To odpowiada Jego własnej naturze, że to ciało na górze przemieniło się w niebieską chwałę, że On poprzez swoją naturę odpędził gorączkę, że przy po mocy śliny pozwalał na odzyskanie wzroku" 38 .

Wszystkie te teksty wskazują, że Hilary wykazuje wyraźną tendencję ubóstwienia ludzkiej natury Chrystusa i wskazuje na jego uduchowione ciało.

Z tego również wynika pewna zauważalna dwutorowość myśli Biskupa Poitiers na temat kondycji ludzkiego ciała w Chrystusie: z jednej strony Chrystus dzielił z nami cielesne właściwości i potrzeby, a z drugiej właściwości ciała Chrystusa przekraczały naturalne ograniczenia ludzkiego ciała. Zdaje się to wynikać z polemiki antyheretyckiej, jaką Hilary toczył podczas swojego duszpasterzowania nie tylko z Ariuszem i jego zwolennikami, ale także z Fotynem ${ }^{39}$. Fotyn i Ariusz doszli do wniosku, że Chrystus jest tylko zwyczajnym człowie-

${ }^{36}$ In Matthaeum I 3, SCh 254, 94-96.

37 De Trinitate X 27, CCL 62A, 482-483: ,Anne timuit, qui armatis ad corripiendum se obvius prodiit? Et in corpore eius infirmitas fuit, ad cuius occursum consternata persequentium agmina conciderunt, et maiestatem ingerentis se ad vincula non ferentes supinatis corporibus recciderunt? Quam igitur infirmitatem dominatam huius corporis credis, cuius tantam habuit natura virtutem"?

38 Tamze X 23, CCL 62A, 478: „Quid per naturam humani corporis conceptam ex Spiritu carnem iudicamus? Caro illa, id est panis ille, de caelis est, et homo ille de Deo est: habens ad patiendum quidem corpus, et passus est, sed naturam non habens ad dolendum. Naturae enim propriae ac suae corpus illud est, quod in caelestem gloriam conformatur in monte, quod adtactu suo fugat febres, quod de sputu suo format oculos".

${ }^{39}$ Fotyn z Sirmium głosił radykalny adopcjanizm, odrzucając w konsekwencji rzeczywiste wcielenie się Boga; Chrystusa uważał za zwykłego człowieka, w którym Logos jest jakby pozornie samoistnym podmiotem, por. G. L. Müller, Chrystologia, dz. cyt., s. 306, 334. 
kiem, i choćby cierpienie związane z męką przypisywane Logosowi dowodzi jego nierówności z naturą Ojca ${ }^{40}$. Stąd $z$ jednej strony Hilary ma odwagę przyjąć poważnie ziemskie, ludzkie zdarzenia w Chrystusie, ale z drugiej strony pokazuje natychmiast przy każdej ziemskiej właściwości życia Jezusa, Jego boską stronę ${ }^{41}$. Taką tezę zdaje się potwierdzać następująca wypowiedź Biskupa Poitiers:

\begin{abstract}
„Chrystus narodził się z Dziewicy, ale według Pisma począł się z Ducha Świętego. Chrystus płakał, ale stosownie do Pisma, to co sprawiało, że płakał, było także podstawą do radości. Chrystus odczuwał głód, ale według Pisma Chrystus jako Bóg wystąpil przeciwko drzewu, które nie rodziło owoców, gdy On sam pozbawiony był pokarmu. Chrystus cierpiał, ale według Pisma będzie siedział po prawicy mocy. On skarżył się, że zostanie na śmierć skazany, ale stosownie do Pisma wziął ze sobą tego, który wyznal wiarę w Niego i że go przyjmie do rajskiego Królestwa. On umarł, ale według Pisma powstał i siedzi po prawicy Pańskiej jako Pan"42.
\end{abstract}

$\mathrm{Z}$ jednej strony jest tutaj widoczna tendencja do ubóstwienia ludzkiej natury Chrystusa, z drugiej zaś ukazana w Chrystusie jedność tego, co cielesne i boskie ${ }^{43}$.

\title{
III. JEDNOŚĆ SEOWA WCIELONEGO
}

Tytułem podsumowania tej części wypowiedzi możemy więc z całą pewnością stwierdzić, że św. Hilary z Poitiers porusza się zasadniczo w kręgu kościelno-tradycyjnej chrystologii i uznaje zarówno pełne bóstwo jak i człowieczeństwa Chrystusa. W jaki sposób jednak w związku z tym ujmuje kwestię relacji pomiędzy bóstwem a człowieczeństwem w Chrystusie? Jak mają się w Nim do siebie te dwie tak różne natury, boska i ludzka? Ostateczna odpowiedź Kościoła w tej kwestii wyrazi się w przyszłości w nauce papieża Leona Wielkiego, zawartej w jego liście do biskupa Konstantynopola Flawiana i w nauce Soboru Chalcedońskiego. Rodzi się jednak pytanie, jaki jest głos w tej sprawie Hilarego, który żył i nauczał blisko sto lat przed Soborem Chalcedońskim?

${ }^{40}$ Por. A. Orazzo, La salvezza, dz. cyt., s. 50-51.

${ }^{41}$ Por. A. Grillmeier, Jesus Christus im Glauben der Kirche, dz. cyt., s. 586.

42 De Trinitate X 67, CCL 62A, 522-523: „Natus ex virgine Christus est, sed secundum scribturas conceptus de Spiritu Sancto est. Flevit Christus, sed secundum scribturas, ut in eo quod flevit gratulatus sit. Et esurivit Christus, sed secundum scribturas sine cibo in non habentem fructus arborem Deus operatus est. Passus Christus est, sed secundum scribturas tunc a dextris virtutis sessurus est. Derelinqui se ad mortem quaestus est, sed secundum scribturas tunc confessorem suum se cum in regno paradisi recepit. Mortuus est, sed secundum scribturas resurgens a dextris Domini Dominus adsedit".

${ }^{43}$ Por. Grillmeier, Jesus Christus im Glauben der Kirche, dz. cyt., s. 586. 
Biskup Poitiers jasno deklaruje, że Chrystus, pomimo owego dualizmu, jaki wyraża się w Jego bóstwie i człowieczeństwie, pomimo, jak wskazaliśmy powyżej, dostrzegania w tajemnicy wcielenia „exterior accessio”, jest tylko jeden. W De Trinitate ujmuje to krótko w następujących słowach: „Nie jest kimś innym Syn Człowieczy od Syna Bożego"44. Nieco dalej w tym samym traktacie jeszcze dokładniej wyraża swoje przekonanie o jedności Słowa Wcielonego, gdy pisze:

„Nie można Go rozdzielać we wszystkich tych tajemnicach, tak aby On był podzielony, aby nie był dłużej Chrystusem: ponieważ Chrystus który przyjął postać sługi nie jest różnym od tego, który był w postaci Boga; ani ten, który umarł, nie różni się od tego, który się narodził; podobnie ten, który zmartwychwstał, od tego, który umarl; ani ten, który jest w niebiosach, od tego, który zmartwychwstał; wreszcie Chrystus, który przedtem zstąpił z nieba, nie jest różny od tego, który jest w niebiosach" ${ }^{45}$.

Słowa te wyraźnie deklarują tożsamość Chrystusa. Jeden i ten sam Chrystus jako Słowo był w postaci Boga, jako Słowo Wcielone przyjął postać sługi, wreszcie ten sam Chrystus po swoim wniebowstąpieniu przebywa w niebiosach.

W związku z tym należałoby postawić kolejne pytanie, w jaki sposób Biskup Poitiers próbuje wyjaśnić tę jedność bóstwa i człowieczeństwa w Chrystusie? W wyjaśnieniu istoty i godności poczęcia Chrystusa mocą Ducha Świętego Hilary stwierdza, że Duch Święty tchnąc dokonał połączenia (immiscuit) się z naturą ludzkiego ciała ${ }^{46}$. Podobnie w Tractatus super Psalmos Biskup Poitiers podkreśla, że w tajemnicy wcielenia nastąpiło przemieszanie ewentualnie dodanie (admiscere) natury ludzkiej do natury boskiej ${ }^{47}$. Uważna lektura choćby wskazanych powyżej wypowiedzi św. Hilarego pozwala zauważyć, że na dziesiątki lat przed Soborem Chalcedońskim Hilary nie przedstawił jeszcze w zasadzie żadnej teorii co do istoty jedności, jaka w Chrystusie nastąpiła pomiędzy bóstwem a człowieczeństwem. Biskup Poitiers raczej w bardziej opisowy sposób przedstawił swoje ujęcie skoncentrowane wokół pojęć ,admiscere” czy „,immiscere”, co pozwala wnioskować, że dostrzegał on w całej ziemskiej rzeczywistości Chrystusa mieszaninę bóstwa i człowieczeństwa ${ }^{48}$.

${ }^{44}$ De Trinitate X 19, CCL 62A, 473: „Non alius filius hominis, quam qui Filius Dei est”.

45 De Trinitate X 22, CCL 62A, 476-477: „Non potest in his sacramentorum diversitatibus ita ab se dividuus esse, ne Christus sit: cum non alius Christus, quam qui in forma Dei erat, formam servi acceperit; neque alius quam qui natus est, mortuus sit; neque alius quam qui mortuus est, resurrexerit; neque alius quam qui resurrexit, sit in caelis; in caelis autem non alius sit, quam qui descendit ante de caelis".

${ }^{46}$ Por. tamże II 26, CCL 62, 62.

47 Por. Tractatus super Psalmos 54,2, CSEL 22, 147-148.

${ }^{48}$ Por. A. Grillmeier, Jesus Christus im Glauben der Kirche, dz. cyt., s. 588. 


\section{SENS TAJEMNICY WCIELENIA}

Jaki sens miało więc wydarzenie wcielenia? Myśl teologiczna św. Hilarego, która sugeruje odpowiedź na to pytanie, utrzymana jest w kategorii myśli historiozbawczej. Wcielenie jest tajemnicą zbawienia człowieka. Podczas antyariańskiej polemiki Biskup Poitiers stawia pytanie:

„Dlaczego ty bezbożnie wypaczasz wcielenie? Dlaczego na śmierć atakujesz tajemnicę naszego zbawienia" ${ }^{49}$.

Natomiast w Komentarzu do Ewangelii św. Mateusza Hilary podkreśla, że Chrystus jest w ciele, które przyjął od człowieka dla zbawienia człowieka ${ }^{50}$. Skutkiem tajemnicy wcielenia według Biskupa Poitiers jest dla ludzi otrzymanie daru synostwa Bożego. Od momentu, gdy Chrystus wziął na siebie nasze słabości, mamy wspólnego z Nim Boga i Ojca ${ }^{51}$. Dzięki wcieleniu poznaliśmy Ojca, tym zaś, który daje nam możliwość poznania Ojca, jest przede wszystkim wcielony $\mathrm{Syn}^{52}$. Wcielenie jest dobrodziejstwem ze strony Boga, dzięki któremu objawia się nam Ojciec i Syn ${ }^{53}$.

Dobrodziejstwem, jakie wynika $z$ wcielenia jest jednak nie tylko poznanie Ojca i Syna, ale także inne pozytywne skutki dla człowieka. Przez zaistnienie Boga w ciele nastąiło odrodzenie człowieka ${ }^{54}$. Wreszcie tajemnica wcielenia daje chrześcijaninowi możliwość osiągnięcia w swoim życiu dobrych owoców. Celem ukazania tej prawdy Biskup Poitiers odnosi w jednej ze swych wypowiedzi tajemnicę wcielenia do ukazanego przez Chrystusa w Ewangelii obrazu winnej latorośli i gałązek:
„Ale następnie wyjawia On tajemnicę przyjęcia ciała, przez które my tkwimy jakby gałązki w winnej latorośli, i gdyby on nie stał się winną latoroślą, my nie mogli- byśmy przynieść żadnego dobrego owocu. I dlatego On nas napomina, abyśmy trwali w Nim przez wiarę w przyjęte ciało, że ponieważ Słowo stało się ciałem, my tkwimy w naturze Jego ciała jak gałązki w winnej latorośli”, ${ }^{, 55}$.

${ }^{49}$ De Trinitate IX 56, CCL 62A, 435: „Quid dispensationem ad inpietatem rapis? Quid sacramentum nostrae salutis invadis ad mortem"?

${ }^{50}$ Por. In Matthaeum 16,9, SCh 258, 56: ,humanae salutis causa Christus in corpore est quod adsumpsit ex homine".

51 Por. De Trinitate XI 10, CCL 62A, 539.

52 Por. tamże IX 50, CCL 62A, 427-428.

53 Por. tamże III 22, CCL 62, 93-94.

54 Por. tamże II 25, CCL 62, 61.

55 Tamże IX 55, CCL 62A, 434: „Corporeae tamen adsumptionis statim mysterium pandens, per quam ei tamquam in vite modo palmitis inessemus, fructum nobis ut palmitibus, nisi ille vitis esset effectus, utilem non daturis. Adque idcirco manere nos in se per fidem adsumpti corporis monet, ut quia verbum caro factum est, naturae carnis suae tamquam viti palmites inessemus". 


\section{THE TEACHING OF SAINT HILARY OF POITIERS ABOUT INCARNATION OF WORD}

(Summary)

The author of the article presents the teaching of Saint Hilary about Incarnation of Christ, how bishop of Poitiers understands: the form of God and form of servant, the eternal birth of Word by Father, the real Deity and human nature of Christ, the question of soul human and body of Christ, the unity of Word Incarnate and meaning of Incarnation's mystery. 